Article received on July $26^{\text {th }} 2016$

Article accepted on November $28^{\text {th }} 2016$

UDC: 78.01 Булез П.

78.071.1 Малер Г.

Anja Lazarevic*

\title{
BOULEZ'S ORIENTATION TOWARDS UNDERSTANDING THE BEGINNINGS OF CONTEMPORARY MUSIC: "MAHLER - OUR CONTEMPORARY?"
}

\begin{abstract}
The central part of Orientations - the collected writings of Pierre Boulez is based on Boulez's mostly short texts about composers whom he considered relevant for his oeuvre and contemplations of music. In addition to other texts, in the part of the book entitled "Examples", Boulez wrote three chapters on the composer Gustav Mahler. Besides Orientations, Boules often spoke about Mahler in his interviews and at lectures he gave. His idea of Mahler was in fact the idea of the beginnings of contemporary music. Considering Boulez's sharp sentences, we come across a wealthy network of judgements about Mahler and his wide influence on twentieth century music, and we acquire a better understanding of Mahler, who, according to Boulez's statements, could be understood only from the perspective of contemporary music.
\end{abstract}

Key words: Pierre Boulez, Orientations/writings, interviews, twentieth century music, Gustav Mahler, influences

In the manifold artistic personality of Pierre Boulez, it is difficult to 'separately' think of Boulez - the composer, Boulez - the conductor and Boulez - the music writer. When asked whether he thought of himself as a composer who conducted or a conductor who composed, Boulez replied: "I am a composer who conducts because conducting entered my life somewhat later". ${ }^{1}$ Boulez himself hardly separated his artistic activities and interests, and the previous question becomes more complex when combined with the dimension of a music writer.

\footnotetext{
* Author contact information: anjalazarevic@yahoo.com

1 From the interview with Charlie Rose in 1999. The record of the interview can be found on https://www.youtube.com/watch?v=oG9G9W46EHU, from 5:55-6:00 min.
} 
During his long career, Pierre Boulez wrote incessantly about music. Composing and conducting inspired him to write and vice versa. The variety of topics, which he used as theoretical, aesthetic and philosophical starting-points for writing, ranked Boulez among the most significant music writers and composers of the twentieth and twenty-first centuries. He continued a well-known series of French composers and writers including Jean-Philippe Rameau, Hector Berlioz, Claude Debussy and Oliver Messiaen. On the other hand, in the German music tradition were Robert Schumann, Carl Maria von Weber, Richard Wagner and Arnold Schoenberg. Boulez must have been aware of the heritage left to their "heirs" by the mentioned composers. Among contemporaries, Boulez had three significant colleagues in this context: John Cage, Karlheinz Stockhausen and Elliott Carter. In comparison to his contemporaries Boulez is specific for the variety of topics of interest. In Boulez - the writer, we recognize a theoretician (just like his professor Messiaen was), occasional music critic (such as Schumann and Debussy) and a historian and a very pragmatic speculator.

Orientations is one of the most significant collection of writings by Boulez; a compilation of essays on a variety of topics which the writer considered together with his views of music. Contemporary music, i.e. its beginnings was the topic that always intrigued Boulez; he wrote about it and gave numerous interviews dedicated to it. His written and spoken discourse related to the composers in the nineteenth and the beginning of the twentieth century always included his speculations about their contribution to the beginnings of contemporary music and, on the other hand, the inspiration which contemporary composers could gain by studying the works of their forerunners. This historical continuity and the awareness of its significance, which Boulez considered extremely important, are obvious in the central part of Orientations where Boulez's writings included composers from Ludwig van Beethoven to Messiaen. It seems that until recently these texts did not intrigue the professional public seriously, and were less known than Boulez's writings where he discussed specific problems of contemporary music or the issues of form (like in the text Alea in 1957). As one of the most significant composers in the above stated collection of texts, Gustav Mahler occupies a prominent place. Three sub-chapters are dedicated to him: "Mahler: why biography?", "Mahler: our contemporary?", and "Mahler: Das Lied von der Erde". The text "Mahler: our contemporary?" appears to be especially significant in the context of Boulez's dedication to the issues of contemporary music and its connection to the history of music.

Mahler's oeuvre was very significant for Boulez as a composer. Also, Mahler was one of the most respected conductors in the second half of the nineteenth and the beginning of the twentieth century, i.e. the period of the European fin de siècle, which brought Boulez even closer to this composer - conductor. 
Like Mahler, Boulez did not have a formal education as a conductor, only as a composer. They were both strong personalities with inflexible attitudes, and although they respected tradition they were hardly ever ready to compromise. They both dedicated themselves more seriously to conducting for additional earnings, in order to cover the expenses of publishing and performing their music more easily. However, their love of conducting soon outgrew their initial ambition and developed into a serious parallel career. Considering Mahler's "juggling" with both of his professions, at the beginning of his essay "Mahler: our contemporary?" Boulez seemed to have re-evaluated whether he himself was equally successful. He wrote: "Too much of a conductor and not enough of a composer; at best, a composer who could not get rid of the conductor in himself'. ${ }^{2}$ With the very title of the essay, Boulez asked an intriguing question which was in the focus of his contemplations - whether Mahler could be considered a contemporary. In other words, whether Mahler's music was so significant for the changes which occurred in music at the beginning of the twentieth century. Certainly, such a question could not be considered unless indisputable axioms spoke in favour of the idea that Mahler's music had to be considered in this respect. One should bear in mind the time when Boulez's writing appeared. He wrote it in 1979 as a Preface to a French edition of the book Gustav Mahler et Vienne by Bruno Walter. When Boulez wrote the essay, as the author delicately alluded, Mahler's oeuvre was still poorly commented. Thus Boulez became one of the first composers who 'audibly' drew attention to the significance of Mahler's oeuvre and the necessity for the re-actualization of its study by young composers (until then, Mahler's "renaissance" was done mostly by musicologists and conductors).

Although in the 1950's and '60s he established his position as one of the most pronounced representatives of avant-garde music and was considered 'radical', Boulez's aesthetics and poetics changed with time. What remained constant were his heroes and composers he considered most significant for the advancement of music towards contemporary trends. It was then, in the 1950's that he revealed the oeuvre of Gustav Mahler. "I discovered Mahler's music in 1958 through his solo songs. ${ }^{3}$ During the next fifty years Boulez regularly performed Mahler's pieces, thus becoming one of the foremost conductors of Mahler's works. He made numerous recordings with various orchestras; he recorded all of Mahler's Symphonies and the Adagio from the unfinished Tenth (he recorded

2 Pierre Boulez, Orientations - Collected Writings, Jean-Jacques Nattiez (Ed.), Cambridge, Harvard University Press, 1986, 295.

${ }^{3}$ Boulez's interview with Jörg Königsdorf in 2007, http://www.signandsight.com/features/1177.html, ac. 20 July 2016. 
the Eighth and Ninth Symphonies twice and the Fifth even three times), Das Lied von der Erde, The Song of the Earth, Rückert Songs, the collection of songs The Youth 's Magic Horn as well as Songs of a Wayfarer. The reason why Boulez was so interested in Mahler's oeuvre for more than half a century was the position of Gustav Mahler in the history of music. The composer who was always at the crossroads between Romanticism and Modernism during his career fascinated Boulez, "with a position between these two epochs". ${ }^{4}$ One of Boulez's recent statements was related to this ambivalence of Mahler's; "As a composer, he reminds me of the god Janus who looked both backwards and forwards at the same time. One face was turned to the past since it was coming from very powerful tradition. Then he gradually withdrew from it. The further he went, the more he turned to the future, never abandoning the past".

On the other hand, from the very beginning of his professional engagement with music, Boulez spoke and wrote how important the Second Viennese School was to him, i.e. the composers Arnold Schoenberg, Alban Berg and Anton Webern. All of those composers had the deepest respect for Gustav Mahler as well, and considered him a significant hero (especially Schoenberg and Berg). ${ }^{6}$ For instance, Boulez thought that "Mahler's music was closely connected with Berg's because they both had the same kind of sensibility. Berg only used a new vocabulary, while Mahler's music should be listened to with the ear of the nineteenth century, without being too disturbed". ${ }^{7}$ In his interviews Boulez often mentioned Mahler. The context in which he spoke of Mahler was related to his presentiment of new tendencies or their indications in the works he created. Boulez thought that extended tonality was Mahler's trademark, and that he went too far in the indication of future tendencies, although he believed that Mahler would never completely abandon the 'grammar' of tonality. In his interview on Mahler given for Universal Edition, Boulez said that he had discovered Mahler thanks to the Second Viennese School, but also that he was capable of complete-

\footnotetext{
${ }^{4}$ Ibid.

5 Pierre Boulez, in "Autopsy of a Genius", documentary, director Andy Sommer, Euro-Art, ARTE France, 2011, from 2:39-2:55 min. It is interesting that Boulez made a comparison with Janus - the Roman god of transition from one season to the other, a keeper of the whole world and the universe. It is also metaphorical that Janus often had keys with him, and as there are many preserved sculptures of this god, we can see that it is always presented with two faces: one looking into the future and the other looking into the past.

${ }^{6}$ At the beginning, Mahler was the most important hero for Schoenberg and Berg. They personally knew each other, and Mahler 'opened' many doors to them in the world of music and was their strong support.

7 Boulez's interview with Jörg Kőnigsdorf in 2007, http://www.signandsight.com/features/1177.html, ac. 20 July 2016.
} 
ly understanding the works of composers of the Second Viennese School only after he became acquainted with Mahler's music. "I started looking backwards through Schoenberg, Berg and Webern to Mahler, and only then was I able to understand Wozzeck better, saying: Yes, I see where it comes from". ${ }^{8}$ Mahler not only indirectly influenced Boulez through the Second Viennese School, but also directly: "Although you would never say that my music stylistically reminds you of Mahler's, I was certainly influenced by the basic principles of his music: the concept of time and the attempt to constantly obtain various perceptions of the same musical material". ${ }^{9}$ Boulez's explanation that he only conducted the music which interested him spoke in favour of this statement, ${ }^{10}$ and he often conducted Mahler's works.

By analysing Boulez's writings one may conclude that the leading figure of the Second Viennese School, Schoenberg, influenced him not only as a composer but also as a music writer. Through the prism of Mahler's oeuvre in the text "Mahler - our contemporary?" Boulez discussed the attitude towards Mahler in the twentieth century and music in general at the end of the nineteenth century, employing his specific sharp style and essay-like contemplations. Boulez found the greatest problem in the aspirations towards 'modern' throughout the twentieth century, which was manifested in complete rejection of the music from the 'turn of the century', ironically concluding that "everything related to fin de siècle music was directed against the burgeoning of new music". ${ }^{11}$ In Boulez's opinion, Mahler, like many other composers, was automatically labelled an old-fashioned author who did not have anything to offer to contemporary music. In addition, his Jewish origin was an additional aggravating circumstance throughout the twentieth century. From all points of view Boulez considered the overall aspects of the non-performance of Mahler's music and not writing about his music together with the disinterest of many young composers to study it. However, his words still imply disbelief in the factual situation, and he loudly and clearly criticized all who had forgotten Mahler. Boulez said: "Goodbye, romanticism with your fatty degeneration of the heart! Goodbye? When works insist on surviving, there can be no goodbye... You dismiss them? Roughly? They obstinately refuse to go away! With pride! [...] Were we guilty or superficial?"'12

${ }^{8}$ Universal Edition Mahler Interview, https://www.youtube.com/watch?v=bfLoQ1fDvEQ, from 6:48-7:35 min.

9 Tbid.

${ }^{10} \mathrm{Cf}$. Ibid.

11 Pierre Boulez, "Mahler - Our Contemporary?", in: Orientations - Collected Writings, Jean-Jacques Nattiez (Ed.), Cambridge, Harvard University Press, 1986, 296.

12 Ibid. 
In Boulez's opinion, Romanticism was understood as something that should be fought against; but in this fight many neglected to discover in Mahler's works what they were fighting for. Boulez saw disbelief in Mahler's music as a crucial problem; this disbelief was so strong that it led to doubts about the Second Viennese School as the group which was simply a more modern version, i.e. "appendix" to the Viennese fin de siècle, as the author himself formulated it. Boulez was certainly not among the first who restored Mahler's position in the history of music to which this composer was entitled; Theodor Adorno had done it twenty years earlier. However, Boulez was one of the first who raised their voice against this historical injustice and who pointed to the Expressionist and generally 'modern' quality of Mahler's music. Boulez thought that cases like Mahler's were "bitter lessons" which composers of the twentieth century had to learn. Although he claimed that no composer should create what could have been composed in the previous epochs, he considered the "absorption of the past" to be vital. He said that various influences thus awakened the individualism of a composer. ${ }^{13}$ "When you have composers like Wagner and Mahler preceding you, let us take only these two examples who arrived at many solutions which are still challenging, you cannot simply say that everything was too complex and that the essence is in our simplifying everything". ${ }^{14}$ Basically, Boulez always spoke and wrote that each generation of composers had to find its own solutions. Indeed, for this reason he respected Mahler deeply. He considered Mahler a composer who combined the 'incompatible' in his works; starting from the poetics of Romanticism he often realised his ideas by using modern means, and announced numerous changes in music which were to become some of the key characteristics of Expressionism and the oeuvre of the Second Viennese School. It was while listening to Schoenberg's Pierrot Lunaire that Boulez wished to begin composing himself.

Gustav Mahler did exactly what Boulez advocated - he had considerable knowledge of the past, which enabled him to properly create something new on the existing foundations, with the exception that Boulez 'broke' more easily with tradition. Boulez saw Mahler's break with the programmatic music of the 'New German School' by removing the titles of symphonies and movements as one of his most significant steps opposing tradition.

Philip Huscher described Boulez's process of composing in the following way: "The idea of one piece often leads to the next composition, the works permanently grow and expand, to be reconsidered with time. Mahler is the best

13 From the interview with Boulez done by Andrew Carvin and Joshua Cody in Paris, 1993, http://www.rodoni.ch/busoni/tecadiarticoli/teca2/boulez.html, ac. 4 July 2016.

14 Ibid. 
match for Boulez from the previous times. Each Boulez score is a component of one magnum opus in evolution". ${ }^{15}$ During his whole career Mahler was in perpetual fear of stagnation, considering it the most devastating thing for a composer. One of the reasons why Mahler devoted himself to Schoenberg and his followers was to acquaint himself with the ideas of the new generations. It was this characteristic of Mahler's that certainly attracted Boulez, who repeatedly wrote and spoke of a composer's work as a permanent movement forward. When asked what he had learnt from Mahler as a composer, Boulez replied: "I learnt much. Firstly concerning distance. Great distance - how to organise a long piece. You have to organise your concept of time differently, you have to organise all those ideas again, without losing their recognisability". ${ }^{16}$ It is necessary to emphasize that Boulez was one of the rare composers and conductors who paid equal attention to Mahler's symphonies and cycles of solo songs. On this point, Boulez claimed that Mahler was not only a master of organisation of large forms but he also "created miniatures and large-size images equally well" ${ }^{17}$ Without analysing too many details in Orientations and many other interviews, Boulez pointed out the innovativeness of Mahler's orchestration and the structure of the orchestra. He thought that Mahler had succeeded in finding an ideal balance between the "weight" (as he used to say) of various instruments or groups of instruments. "The ratio of dynamics is also very important - he knew exactly what to demand from each instrument related to its weight, register and timbre". ${ }^{18}$ In Boulez's opinion, Mahler's contribution to orchestration in twentieth century music was as significant as his contribution to the composing and organisation of the musical form.

"I always say - each period is difficult. There is no easy period" ${ }^{19}$ Like many others, Boulez saw Mahler's oeuvre and his ideas of music as very progressive for the time and place of their creation and also for their presentation to the audience. The problems with the reception of Mahler's pieces during the composer's lifetime were not found in music, but in the incomprehension of the majority of audiences and critics who were 'lulled' in the aesthetics of the nineteenth century. Boulez understood Mahler as a composer and conductor who

15 The interview entitled "Dialogues with Pierre Boulez" with Rocco Di Pietro, http://kalvos. org/dipeess1.html.

16 Universal Edition Mahler Interview, https://www.youtube.com/watch?v=bfLoQ1fDvEQ, from 4:52-5:27.

17 Ibid., from 8:38-8:45.

18 Ibid., from 5:28-5:57.

19 From the interview with Boulez done by Andrew Carvin and Joshua Cody in Paris, 1993, http://www.rodoni.ch/busoni/tecadiarticoli/teca2/boulez.html, ac. 4 July 2016. 
managed to agitate "the interior" of a professional audience by his innovative approach to composing and the programmes he conducted. He saw Mahler's oeuvre as one of those which needed time. At the end of the twentieth century he said that "Mahler is much easier today than he was thirty years ago", ${ }^{20}$ thinking of both audiences and performers. "What a time it has taken for his name to emerge, not from the shadows, but from Purgatory!"21 - is the opening sentence of Boulez's writing "Mahler: our contemporary?" to state in the introductory part "what confusion he caused!" 22 With his writings and interviews, Pierre Boulez significantly contributed to clearing the "confusion" related to Mahler's oeuvre, appointing him one of the pioneers of twentieth century music.

\section{References}

Boulez, Pierre, "Mahler - Our Contemporary?”, Orientations - Collected Writings, JeanJacques Nattiez (ed.), Cambridge, Harvard University Press, 1986, 295-303.

Boulez, Pierre, "Mahler - Why Biography?", Orientations - Collected Writings, Jean-Jacques Nattiez (ed.), Cambridge, Harvard University Press, 1986, 292-294.

Campbell, Edward, Boulez, Music and Philosophy, Cambridge, Cambridge University Press, 2010.

Walters, David, The Aesthetics of Pierre Boulez, $\mathrm{PhD}$ thesis, Department of Music, University of Durham, 2003.

${ }^{20}$ From the interview with Boulez done by Jed Distler in 2000, http://www.rodoni.ch/busoni/tecadiarticoli/teca2/boulez.html, ac. 13 August 2016.

21 Pierre Boulez: "Mahler - Our Contemporary?", op. cit., 295.

22 Ibid. 